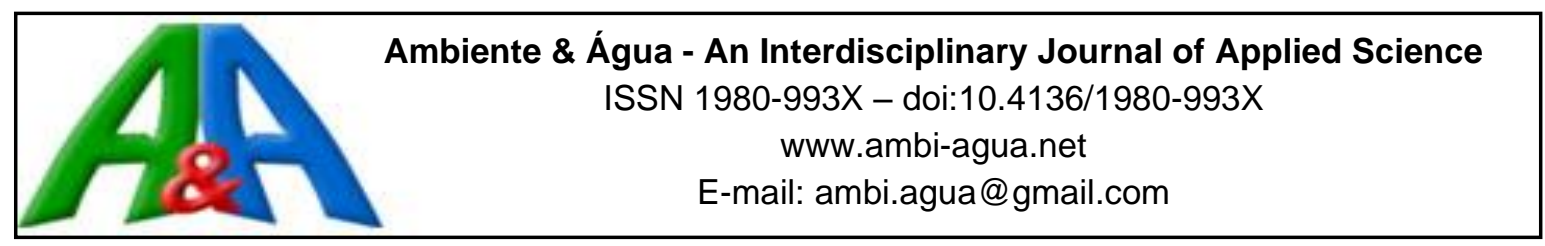

\title{
Wood ash and water availability in the production of Paiaguás-grass
}

\author{
ARTICLES doi:10.4136/ambi-agua.2424
}

Received: 12 Jun. 2019; Accepted: 15 Oct. 2019

\begin{abstract}
Edna Maria Bonfim-Silva ${ }^{1 * i D}$; Maria Débora Loiola Bezerra ${ }^{2}$ iD; Tonny José Araújo da Silva1 ${ }^{1}$; William Fenner ${ }^{2}$; Ana Paula Alves Barreto Damasceno 1 (D)

${ }^{1}$ Instituto de Ciências Agrárias e Tecnológicas (ICAT). Universidade Federal de Mato Grosso (UFMT), Avenida dos Estudantes, n5055, CEP: 78735-901, Rondonópolis, MT, Brazil. E-mail: tonnyjasilva@hotmail.com,pauladamasceno1@yahoo.com.br

${ }^{2}$ Programa de Pós-Graduação em Agricultura Tropical (PPGAT). Faculdade de Agronomia e Zootecnia (FAAZ). Universidade Federal de Mato Grosso (UFMT), Avenida Fernando Corrêa da Costa, n²367, CEP: 78060-900, Cuiabá, MT, Brazil. E-mail: mariadeboralb@outlook.com, fennerwilliam@gmail.com

*Corresponding author. E-mail: embonfim@hotmail.com
\end{abstract}

\begin{abstract}
This study evaluated the production of Paiaguás grass (Urochloa brizantha) as a function of wood-ash doses and water availability in the Cerrado Oxisol. The experiment was carried out in a greenhouse with a randomized block design in a fractioned $5 \times 5$ factorial scheme, corresponding to five wood-ash doses $\left(0 ; 8 ; 16 ; 24\right.$ and $\left.32 \mathrm{~g} \mathrm{dm}^{-3}\right)$ and five soil wateravailability scenarios $(4 ; 8 ; 16 ; 32 ; 64 \mathrm{kPa})$ with four repetitions. The experimental design was based on the modified central compound and consisted of 13 treatments of wood-ash doses $(\mathrm{g}$ $\mathrm{dm}^{-3}$ ) and soil water-availability scenarios $(\mathrm{kPa}): 0-4 ; 0-16 ; 0-64 ; 8-8 ; 8-32 ; 16-4 ; 16-16 ; 16-$ $64 ; 24-8 ; 24-32 ; 32-4 ; 32-16 ; 32-64$. Soil volumetric moisture was monitored daily by means of the Diviner 2000 Capacitance Probe ${ }^{\circledR}$ for soil water replenishment according to the treatments. In 30-day intervals, three cuts were performed in the aerial part of the plants evaluating dry mass of leaves, stems, aerial part, number of leaves and of tillers. Data were subjected to analysis of variance and when significant to regression analysis, both up to $5 \%$ of error probability, through the statistical program SISVAR and response surface study using SAS. The combinations of wood ash doses with water soil tensions influence the productive characteristics of Paiaguás grass. Fertilization with wood ash reduces the effect of water stress on Paiaguás grass and this residue may be a viable alternative to partial replacement of mineral fertilization and safe disposal in the environment.
\end{abstract}

Keywords: forage grasses, nutrients, solid residue in agriculture, volumetric soil moisture.

\section{Cinza vegetal e disponibilidade hídrica na produção de capim-Paiaguás}

\section{RESUMO}

Objetivou-se avaliar a produção do capim-paiaguás (Urochloa brizantha) em função de doses de cinza vegetal e disponibilidades hídricas do Latossolo Vermelho do Cerrado. O experimento foi realizado em casa de vegetação com delineamento em blocos casualizados em esquema fatorial $5 \times 5$ fracionado, correspondendo a cinco doses de cinza vegetal $(0 ; 8 ; 16 ; 24$ e 
$\left.32 \mathrm{~g} \mathrm{dm}^{-3}\right)$ e cinco disponibilidades hídricas do solo $(4 ; 8 ; 16 ; 32 ; 64 \mathrm{kPa})$ com quatro repetições. O desenho experimental foi baseado no composto central modificado e constituía-se por 13 tratamentos de doses de cinza vegetal $\left(\mathrm{g} \mathrm{dm}^{-3}\right)$ e disponibilidades hídricas do solo $(\mathrm{kPa})$ : 0-4; $0-16 ; 0-64 ; 8-8 ; 8-32 ; 16-4 ; 16-16 ; 16-64 ; 24-8 ; 24-32 ; 32-4 ; 32-16 ; 32-64$. A umidade volumétrica do solo foi monitorada diariamente por meio da sonda de capacitância Diviner $2000^{\circledR}$ para reposições hídricas do solo conforme os tratamentos. Em intervalo de 30 dias foram realizados três cortes na parte aérea das plantas avaliando-se a massa seca das folhas, dos colmos, da parte aérea, número de folhas e de perfilhos. Os dados foram submetidos à análise de variância e quando significativo à análise de regressão, ambos até $5 \%$ de probabilidade de erro, por meio do programa estatístico SISVAR e o estudo de superfície de resposta por meio do SAS. As combinações de doses de cinza de madeira com as tensões de água do solo influenciam as características produtivas do capim Paiaguás. A fertilização com cinza de madeira reduz o efeito do estresse hídrico na grama de Paiaguás e esse resíduo pode ser uma alternativa viável à substituição parcial da fertilização mineral e ao descarte seguro no ambiente.

Palavras-chave: gramíneas forrageiras, nutrientes, resíduo sólido na agricultura, umidade volumétrica do solo.

\section{INTRODUCTION}

Brazil has a cattle population of about 171 million heads distributed in more than 158 million hectares (IBGE, 2018). Briefly, one can infer that the supportability of these pastures is equal to 1.08, which represents low productivity and animal performance in view of the pastures' inadequate management, through the production of ruminants from tropical grasses.

Additionally, the tropical regions' soils are known for presenting low natural fertility and high acidity, weathering products in the formation of these soils. One of the biggest challenges is to find economic and ecological solutions for the growing needs of modern society. In this context, the use of waste such as wood ash in agriculture has become an alternative. It can be applied to the soil as fertilizer and as a neutralizer of soil acidity and may provide nutrients to the soil, such as calcium, magnesium, potassium, phosphorus and micronutrients, essential elements for plant growth and development (Hansen et al., 2018; Maresca et al. 2017; Ingerslev et al., 2011). There is evidence that the increase in $\mathrm{pH}$ is greater in soils with low $\mathrm{pH}$ and low organic-matter content (Ohno, 1992), characteristics of tropical soils.

The qualitative and quantitative composition of the wood ash depends on the biomass used; being a product resulting from the incomplete and variable combustion of wood, there is the interference of the carbonization temperature, responsible for the greater or lesser sublimation of chemical components, and the adoption or not of refiring (Maeda et al., 2008). When compared to other types of organic fertilization, such as dung, which are the most common source of organic matter among organic fertilizers (Weinärtner et al., 2006), it is verified that the amount of nitrogen, for example, is much smaller, since it is lost in the biomass burning process, and it is necessary to use another source for its availability.

Wood ash is easily found in areas close to industries that use thermal energy as a source. Due to this, and considering the costs of fertilizers, and that the constant and often inappropriate use of these products may exacerbate environmental problems, wood ash can be considered a viable alternative. Several studies have explored the yield of grass biomass with the objective of using wood ash (Lindyall et al., 2015; Rancane et al., 2015; Bezerra et al., 2016; Reed et al., 2017).

Tropical grassland fertilization using wood ash has been recommended by researchers. In addition to the benefits on soil fertility, as the highest concentration of nutrients phosphorus, potassium and aluminum saturation decrease according to the addition of calcium, wood ash increased pasture production and the nutritional value of forage (Smith et al., 2011). Other 
researchers verified higher growth, biomass production of cultivars of Urochloa brizantha (Bonfim-Silva et al., 2013; 2015; Bezerra et al., 2014; Baloch et al., 2015) and an increase in macronutrient concentrations in forage (Santos et al., 2014; Bonfim-Silva et al., 2014) with the addition of the residue to the soil.

This practice is demonstrated as an integrated strategy in which it reduces costs related to fertilization of degraded and decapitalized pasture soils and contributes to the environmental management of ash residues as an alternative to traditional landfills.

Furthermore, one of the limiting factors in biomass production is water availability. Thus, pasture irrigation is a strategy to maintain forage availability in dry periods or to intensify production (Robins, 2016; Mazahrih et al., 2016; Peacock et al., 2003). Wood ash incorporated into the soil, in addition to providing nutrients, increases soil water-retention capacity (Pathan et al., 2003; Ramesh et al., 2008; Stoof et al., 2010; Pereira et al., 2016) and may decrease the amount of water used in irrigated pastures or even obviate the need for irrigation, especially in adapted cultivars.

The cultivar BRS Paiaguás, belonging to the genus Urochloa brizantha, presents high production potential during the dry season (Euclides et al., 2016; Valle et al., 2013). Thus, the incorporation of wood ash to the soil is expected to achieve high grass production even in soil water tensions higher than those observed by other researchers. In the evaluation of Paiaguás grass under water tension in the soil, higher biomass production and water use efficiency was verified by Paiaguás grass under water tension in the soil from 29 to $34 \mathrm{kPa}$ (Koetz et al., 2017).

In this context, this study evaluated the productive characteristics of Paiaguás grass (Urochloa brizantha) subjected to doses of wood ash and water availabilities cultivated in Cerrado Oxisol.

\section{MATERIAL AND METHODS}

\subsection{Experimental design}

The experiment was carried out in a greenhouse in a randomized block design in a fractioned $5 \times 5$ factorial scheme consisting of five doses of wood ash $(0 ; 8 ; 16 ; 24$ and $\left.32 \mathrm{~g} \mathrm{dm}^{-3}\right)$ and five water availabilities $(4 ; 8 ; 16 ; 32 ; 64 \mathrm{kPa})$ with five replications. The experimental design was based on the modified central compound (Littel and Mott, 1975) in which 13 combinations of wood-ash doses $\left(\mathrm{g} \mathrm{dm}^{-3}\right)$ and soil water availabilities $(\mathrm{kPa})$ were studied, respectively: 0-4; 0-16; 0-64; 8-8; 8-32; 16-4; 16-16; 16-64; 24-8; 24-32; 32-4; 32-16; 32-64.

\subsection{Chemical analysis, particle size and experimental plots}

The soil used was dystrophic Oxisol collected in the layer of $0-20 \mathrm{~cm}$ in an area under Cerrado vegetation, characterized chemically and granulometrically (Table 1) according to EMBRAPA (2017). Subsequently, the soil was sifted into a 4-mm mesh opening to fill the vessels.

Table 1. Chemical and granulometric analysis of dystrophic Oxisol $(0-20 \mathrm{~cm}$ layer $)$ in Cerrado vegetation area, Rondonópolis-MT.

\begin{tabular}{|c|c|c|c|c|c|c|c|c|c|c|c|c|c|}
\hline pH & $\mathbf{P}$ & $\mathbf{K}$ & Ca & Mg & Al & $\mathbf{H}$ & CEC & OM & V & $\mathbf{M}$ & Sand & Silt & Clay \\
\hline $\mathrm{CaCl}_{2}$ & $\mathrm{mg}$ & $\mathrm{dm}^{-3}$ & & & $\mathrm{nol}_{\mathrm{c}} \mathrm{C}$ & $m^{-3}$ & & $\mathrm{~g} \mathrm{~kg}^{-1}$ & & $\%$ & & $\mathrm{~g} \mathrm{~kg}^{-1}$ & \\
\hline 4.1 & 1.1 & 47 & 0.2 & 0.1 & 1.0 & 4.7 & 6.1 & 19.7 & 6.9 & 70.4 & 575 & 50 & 375 \\
\hline
\end{tabular}


The experimental units were composed of pots adapted made with PVC, polyvinyl chloride, described by Pacheco et al. (2018), with $300 \mathrm{~mm}, 200 \mathrm{~mm}$ in diameter, totaling a soil volume of $8.7 \mathrm{dm}^{3}$.

\subsection{Characterization of wood ash}

The composition of the plant material incinerated for the production of wood ash consisted of $30 \%$ eucalyptus and $70 \%$ of other materials, such as brachiaria, corn straw, cotton residue, eucalyptus chips, rubber tree and sugarcane bagasse. The combustion temperature of the plant material was 200 to $250^{\circ} \mathrm{C}$ and the furnace from 820 to $850^{\circ} \mathrm{C}$.

The wood ash presented total neutralization relative power (TNRP) equal to $32.66 \%$, neutralization power (NP) of $21.8 \%$, reactivity (RE) of $149.8 \%$ and density equal to $0.45 \mathrm{~g} \mathrm{~cm}^{-3}$ according to Bonfim-Silva et al. (2018). Wood ash has a water retention capacity of $0.71 \mathrm{~cm}^{3} \mathrm{~cm}^{-3}$ (Martinez-Santos, 2018). The wood ash (Table 2) was applied to the soil, according to the treatments, as source of the nutrients potassium, phosphorus, calcium and magnesium, remaining for a period of 30 days to achieve soil $\mathrm{pH}$-correction reaction.

Table 2. Wood ash chemical composition analyzed as a corrective and fertilizer.

\begin{tabular}{cccccccccccccc}
\hline $\mathbf{p H}$ & $\mathbf{N}$ & $\mathbf{P}_{2} \mathbf{O}_{5}$ & $\mathbf{K}_{2} \mathbf{O}$ & $\mathbf{C a}$ & $\mathbf{M g}$ & $\mathbf{S O}_{4}$ & $\mathbf{Z n}$ & $\mathbf{C u}$ & $\mathbf{F e}$ & $\mathbf{M n}$ & $\mathbf{B}$ & $\mathbf{S i}$ & $\mathbf{N a}$ \\
\hline $\mathrm{CaCl}_{2}$ & \multicolumn{10}{c}{10} \\
\hline 10.7 & 3.1 & 9.6 & 34.7 & 33.0 & 21.0 & 2.0 & 0.1 & 0.0 & 10.3 & 0.4 & 0.1 & 274.4 & 0.1
\end{tabular}

$\mathrm{N}=$ Nitrogen; $\mathrm{P}_{2} \mathrm{O}_{5}=$ Phosphorus in neutral ammonium citrate and water $(\mathrm{NAC}+$ water $)$; $\mathrm{K}_{2} \mathrm{O}=$ Potassium; $\mathrm{Ca}=$ Calcium; $\mathrm{Mg}=$ Magnesium; $\mathrm{SO}_{4}=$ Sulfur; $\mathrm{Zn}=$ Zinc Total $; \mathrm{Cu}=$ Copper Total Mn = Total Manganese $; \mathrm{B}=$ Total Boron; $\mathrm{Si}=$ Silicon; $\mathrm{Na}=$ Sodium .

\subsection{Sowing and fertilizing}

The sowing of the Urochloa brizantha (syn. Brachiaria brizantha) cv. BRS Paiaguás was performed after the incubation period of the soil with wood ash. Five plants were maintained in each experimental unit.

Nitrogen fertilization was $200 \mathrm{mg} \mathrm{dm}^{-3}$, using urea as the source of the nutrient according to the recommendation of Bonfim-Silva et al. (2015). Nitrogen fertilization was applied by solution and in two installments of $100 \mathrm{mg} \mathrm{dm}^{-3}$ each with an interval of seven days, starting at five days after seedling emergence for the establishment of the crop, and seven days after each cutting of the grass. Nitrogen fertilization was necessary due to the lower concentration of $\mathrm{N}$ in the wood ash, which is lost by volatilization at the time of combustion.

\subsection{Water availability and irrigation}

Soil volumetric moisture was related to soil water tension in a pilot experiment using the same soil and doses of wood ash, for determination of the waterslide to be applied in each experimental unit. Water replenishments were performed by the semi-automated drip irrigation system (Pacheco et al., 2018), in order to increase soil moisture to the established values of each treatment $(4 ; 8 ; 16 ; 32$ and $64 \mathrm{kPa})$ (Table 3). The control of soil volumetric moisture was performed by means of the capacitance probe model Diviner $2000^{\circledR}$. The treatments according to the water tension in the soil started together with the application of the wood ash doses, that is, from the soil-ash reaction thirty days before the sowing of the grass. 
Table 3. Soil volumetric moisture (\%) corresponding to the water tension $(\mathrm{kPa})$ of the dystrophic Oxisol subjected to wood ash doses $\left(\mathrm{g} \mathrm{dm}^{-3}\right)$.

\begin{tabular}{|c|c|c|c|c|c|}
\hline \multirow{3}{*}{ Soil Water Tension $(\mathrm{kPa})$} & \multicolumn{5}{|c|}{ Wood ash $\left(\mathrm{g} \mathrm{dm}^{-3}\right)$} \\
\hline & 0 & 8 & 16 & 24 & 32 \\
\hline & \multicolumn{5}{|c|}{ Volumetric moisture (\%) } \\
\hline 4 & 12.84 & 13.66 & 20.04 & 16.34 & 20.36 \\
\hline 8 & 8.50 & 9.82 & 14.51 & 11.54 & 14.78 \\
\hline 16 & 5.63 & 7.06 & 10.50 & 8.16 & 10.73 \\
\hline 32 & 3.72 & 5.08 & 7.60 & 5.76 & 7.79 \\
\hline 64 & 2.47 & 3.65 & 5.50 & 4.07 & 5.65 \\
\hline
\end{tabular}

The water volume applied in soil was calculated using the following Equation 1:

$V=(\theta$ treatment $-\theta$ current $) \times 8700$

Where:

$\mathrm{V}=$ water volume applied $\left(\mathrm{cm}^{3}\right)$;

$\theta$ treatment $=$ volumetric moisture treatment $(\%)$;

$\theta$ current $=$ current volumetric soil moisture $(\%)$;

$8700=$ soil volume in adapted pot $\left(\mathrm{cm}^{3}\right)$.

\subsection{Analyzed variables}

The variables were evaluated at intervals of 30 days, at the time of each cut, until 90 days after sowing. The number of leaves, number of tillers, dry mass of leaves, stems and aerial part were evaluated on the occasion of each cutting.

The number of leaves is the sum of the expanding and expanded green leaves. The mass of leaves and stems were obtained after cutting the plants to a height of $5 \mathrm{~cm}$ above the soil level and weighed on a semianalytical balance. After weighing, the fresh vegetable materials were packaged in paper bags, identified and brought to the forced ventilation stove at $65^{\circ} \mathrm{C}$, for 72 hours (time to obtain the constant mass). The samples were then weighed again to obtain the dry mass.

The aerial part dry mass is the sum of the dry mass of leaves with the dry mass of stems.

\subsection{Statistical analysis}

Data were subjected to analysis of variance, and when significant to regression analysis, both up to 5\% probability of error. For the variables that presented isolated effects, the statistical program SISVAR (Ferreira, 2011) was used, and for the variables that showed significance in the interaction between the sources of variation, the response surface study was carried out by means of the statistical program SAS, Statistical Analysis System (SAS Institute, 2002).

\section{RESULTS AND DISCUSSION}

\subsection{Number of leaves}

In the first and second evaluation, there was a significant interaction between the woodash doses and soil water tension (Figure 1A) for the number of leaves. In the first cut, studying the response surface, the highest number of leaves (82.85) occurred at the wood-ash dose of 32 $\mathrm{g} \mathrm{dm}^{-3}$ related to the soil water tension of $4 \mathrm{kPa}$. 

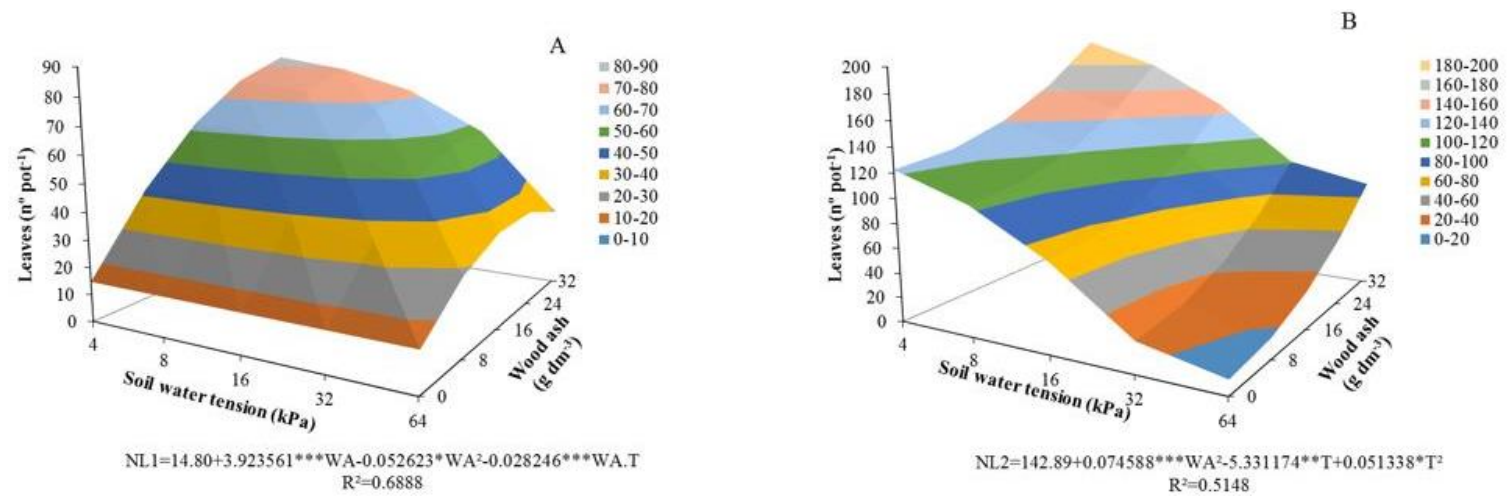

Figure 1. Number of leaves of Urochloa brizantha cv. BRS Paiaguás under wood-ash doses and soil water tensions in the first (A) and second (B) evaluation.

NL1 and NL2 = number of leaves in the first and second cut. WA $=$ Wood ash. $\mathrm{T}=$ soil water tensions. $* * *, * * *$ significant to 5,1 , and $0.1 \%$ probability, respectively.

In the second forage grass cut (Figure 1B), in the response surface study, the wood ash dose of $32 \mathrm{~g} \mathrm{dm}^{-3}$ associated with soil water tension of $51.92 \mathrm{kPa}$ provided the maximum production of leaves (80.87). At 90 days after sowing (third cut), the production of leaves of Paiaguás grass was adjusted to the quadratic regression model. The wood ash dose of $27 \mathrm{~g} \mathrm{dm}^{-3}$ (Figure 2A) promoted the maximum number of leaves of 150.11. The smallest production of grass leaves, 14.63, occurred at the soil water tension of $47.01 \mathrm{kPa}$ (Figure 2B).
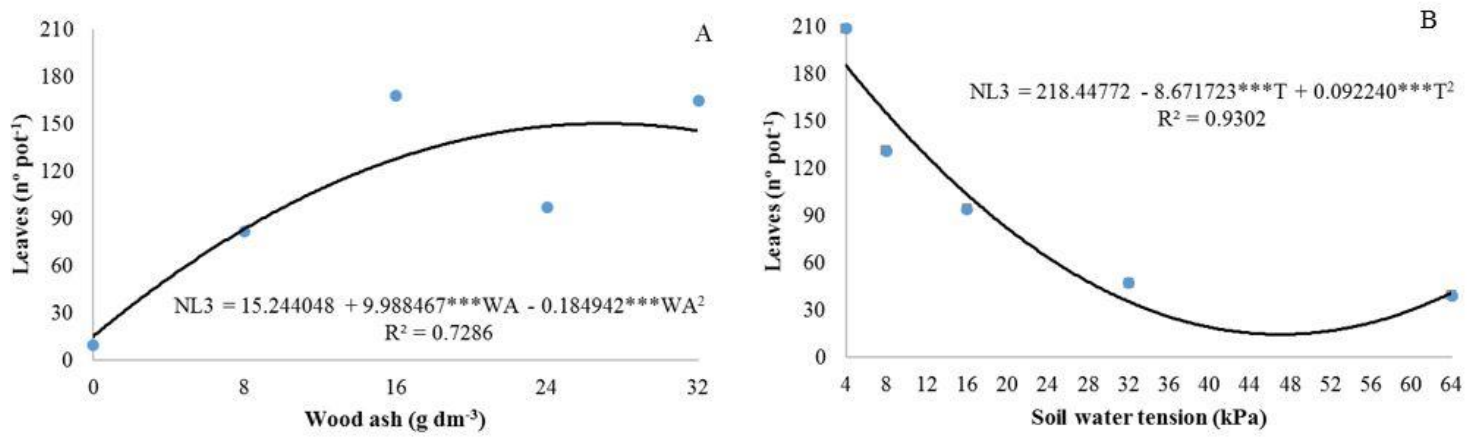

Figure 2. Number of leaves of Urochloa brizantha cv. BRS Paiaguás as a function of woodash doses (A) and soil water tensions (B) in the third cut.

NL3 $=$ number of leaves in the third cut. WA $=$ wood ash. $\mathrm{T}=$ soil water tension. Significant to $0.1 \%$ probability.

The present study corroborates the results of Bezerra et al. (2014), who incorporated wood ash in an Oxisol cultivated with $U$. brizantha cv. Marandu and found an increase in forage-leaf production. Bonfim-Silva et al. (2015), evaluating the effect of wood ash on tropical grasses found an increase of $89.85 \%$ in the number of leaves of $U$. brizantha cv. Marandu, also corroborating the present results.

It was observed, in the second cut, that the largest production of leaves occurred even in conditions of low water availability; this can be attributed to the application of wood ash to the soil, since it increases soil water retention (Chang et al., 1977; Stoof et al., 2010; Pereira et al., 2016). Thus, the importance of using wood ash to increase leaf production and for soil water conservation in dry periods was emphasized, since it still provides nutrients for pastures.

The increase in the number of leaves verified with the increase of the fertilization by wood ash is fundamental for the recovery of the grass after grazing. The formation and development of the leaves contribute to the growth of forage, because they are important components for the leaf-area index (Matthew et al., 2000) and represent part of the active photosynthetic tissue 
where most of the light energy is captured used for production of photoassimilates to the plant (Taiz and Zeiger, 2013).

In addition, the leaves have high nutritive value for ruminants, which associated with a higher density of tillers, can result in higher forage production, and consequently a corresponding increase in the stocking rate and possibly an increase in animal performance (Pereira et al., 2010).

\subsection{Number of tillers}

In the first cut, there was a significant effect of the interaction between the wood ash doses and soil water tension as to the number of tillers. In the response-surface study (Figure 3), the combination of the wood-ash dose of $32 \mathrm{~g} \mathrm{dm}^{-3}$ with the soil water tension of $37.14 \mathrm{kPa}$ provided 18.14 tillers of the Paiaguás grass.

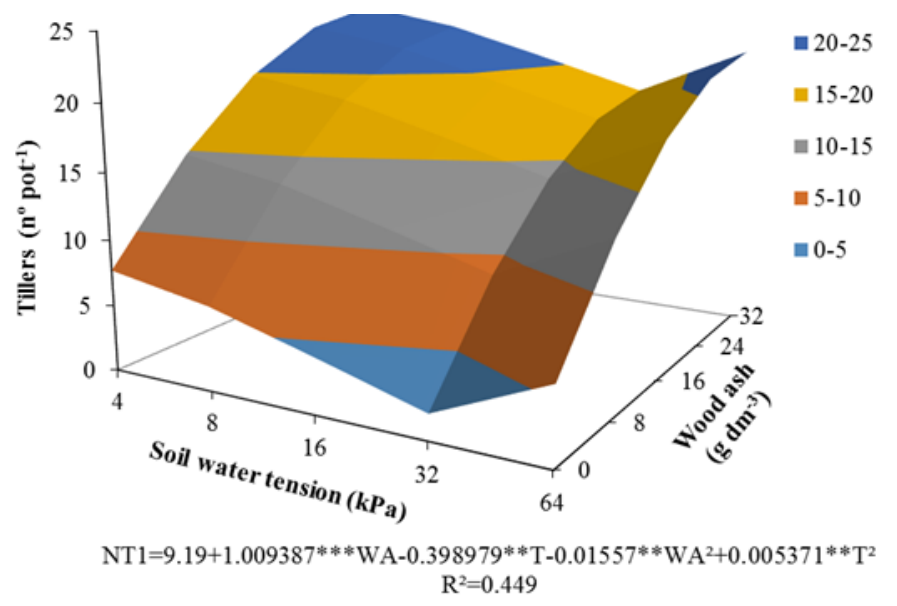

Figure 3. Number of tillers of Urochloa brizantha cv. BRS Paiaguás subjected to wood-ash doses and soil water tension in the first cut.

NT1 = number of tillers in the first cut. WA = wood ash. $\mathrm{T}=$ soil water tension. $* *$ and $* * *$ significant at 1 and $0.1 \%$, respectively.

In the second cut, there was an isolated effect among the treatments for the number of tillers that were adjusted to the quadratic regression model. The maximum number of tillers (39.27) was verified in the wood ash dose of $26.29 \mathrm{~g} \mathrm{dm}^{-3}$ (Figure 4A) and the smallest number of tillers (11.04) in the soil water tension of $48.13 \mathrm{kPa}$ (Figure 4B).
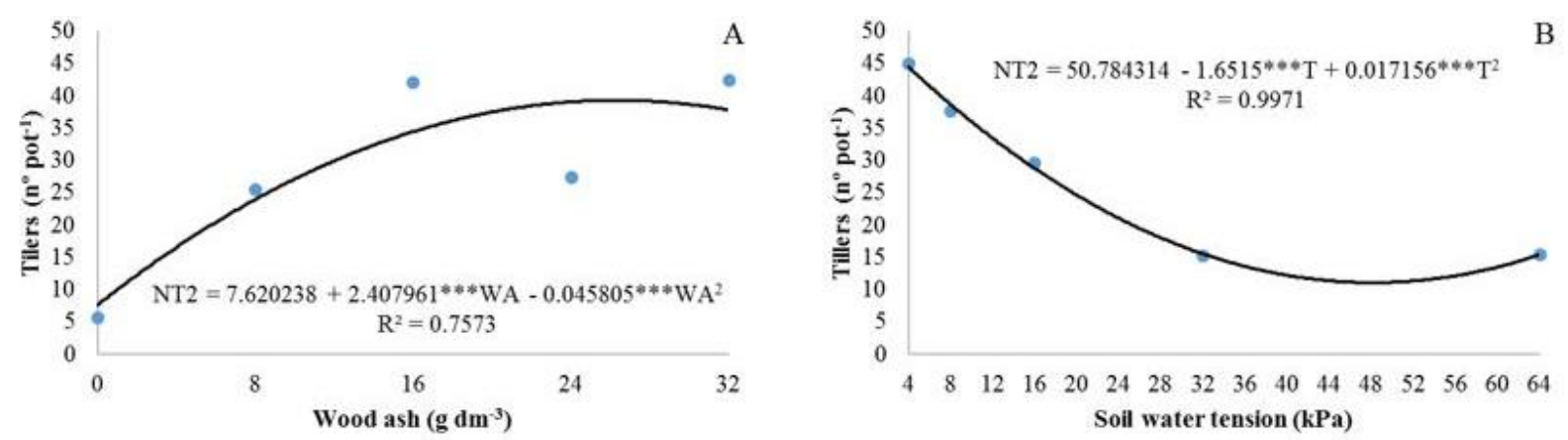

Figure 4. Number of tillers of Urochloa brizantha CV. BRS Paiaguás subjected to wood-ash doses and soil water tension (B) in the second cut.

$\mathrm{NT} 2=$ number of tillers in the second cut. WA $=$ wood ash. $\mathrm{T}=$ soil water tension. The $0.1 \%$ probability. 
In the third cut, there was an interaction between the wood-ash doses and soil water tensions for the number of tillers. In the response surface study (Figure 5), the association of the wood-ash dose of $32 \mathrm{~g} \mathrm{dm}^{-3}$ and the soil water tension of $47.75 \mathrm{kPa}$ promoted the highest tiller production (19.88).

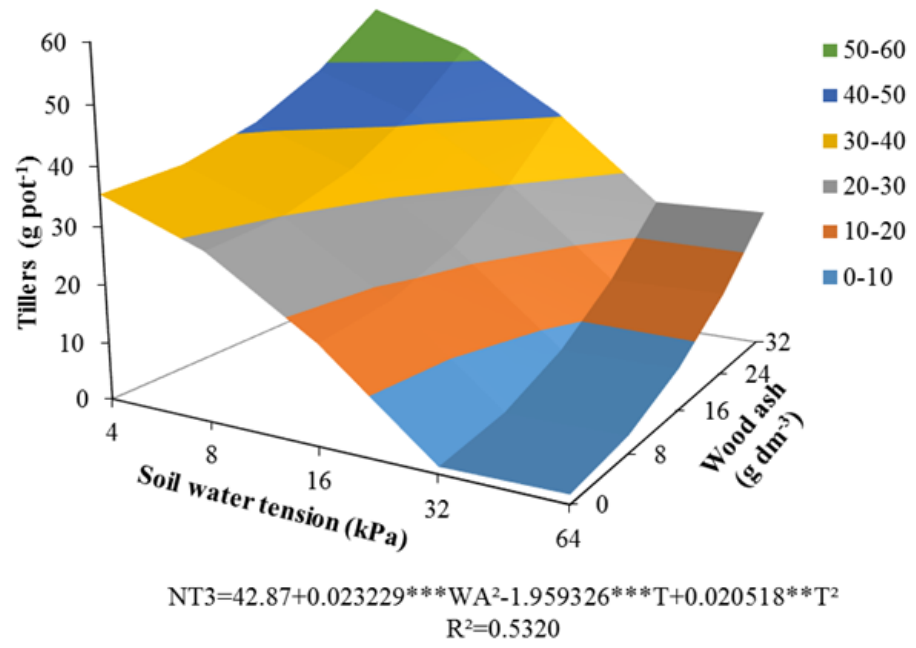

Figure 5. Number of tillers of Urochloa brizantha CV. BRS Paiaguás subjected to wood-ash doses and soil water tensions on the third cut.

NT3 $=$ number of tillers in the third cut. WA $=$ wood ash. $\mathrm{T}=$ soil water tensions. $* *$ and $* * *$ significant at 1 and $0.1 \%$ probability.

It was verified, in the first and third cuts, that higher numbers of tillers of the Paiaguás grass were observed despite high soil water tensions that confer low soil moisture. This occurred due to the addition of organic matter by wood ash that favored soil water retention (Ghodrati et al., 1995; Pathan et al., 2003; Ramesh et al., 2008).

The lower yield of tillers observed in the second cut due to the high soil water tension of $48.13 \mathrm{kPa}$ is due to the response mechanism of the plants to the water deficit that reduces the vegetative growth of organs such as leaves and tillers (Mahajan and Tuteja, 2005; Reynolds et al., 2005). Also, in the second evaluation, there was a higher production of tillers of the grass when fertilized with the wood-ash dose of $26.29 \mathrm{~g} \mathrm{dm}^{-3}$; thus, the use of the burning residue of plant material to improve the tillering and perpetuation of the pastures is emphasized.

Corroborating the results of the present study, Bezerra et al. (2014), when evaluating the productive characteristics of Marandu grass as a function of wood ash, highlighted the potential use of the residue as fertilizer in forage grasses, increasing the production of tillers of the cultivar Marandu in an Oxisol. Researchers showed that fertilization by wood ash influenced the maximum yield of Marandu tillers in all crops, contributing to greater vigor and persistence of grass after grazing (Bonfim-Silva et al., 2015). These authors emphasize that tillers are a structural characteristic of an indicative parameter of forage grass growth.

The number of tillers is higher in pastures with low plant height, and as a consequence they have higher plant density (Evers et al., 2011; Matthew et al., 2000) due to greater penetration of luminosity at the plant base, stimulating/promoting the tillering of the grass. On the other hand, grasses with greater height promote the stretching of the stalk as a strategy to expose the new leaves in the upper canopy region where luminosity is greater.

\subsection{Dry mass of leaves}

In the three assessments, the dry mass of leaves had an isolated effect for the wood ash doses and soil water tensions. In the first cut, the dry mass of leaves was adjusted to the 
quadratic regression model for both sources of variation. The wood-ash dose of $23.09 \mathrm{~g} \mathrm{dm}^{-3}$ (Figure 6A) provided the highest dry mass of leaves of $3.40 \mathrm{~g} \mathrm{pot}^{-1}$. In the soil water tension of $53.36 \mathrm{kPa}$, the lowest dry mass of leaves of $0.94 \mathrm{~g} \mathrm{pot}^{-1}$ (Figure 6B) was obtained.
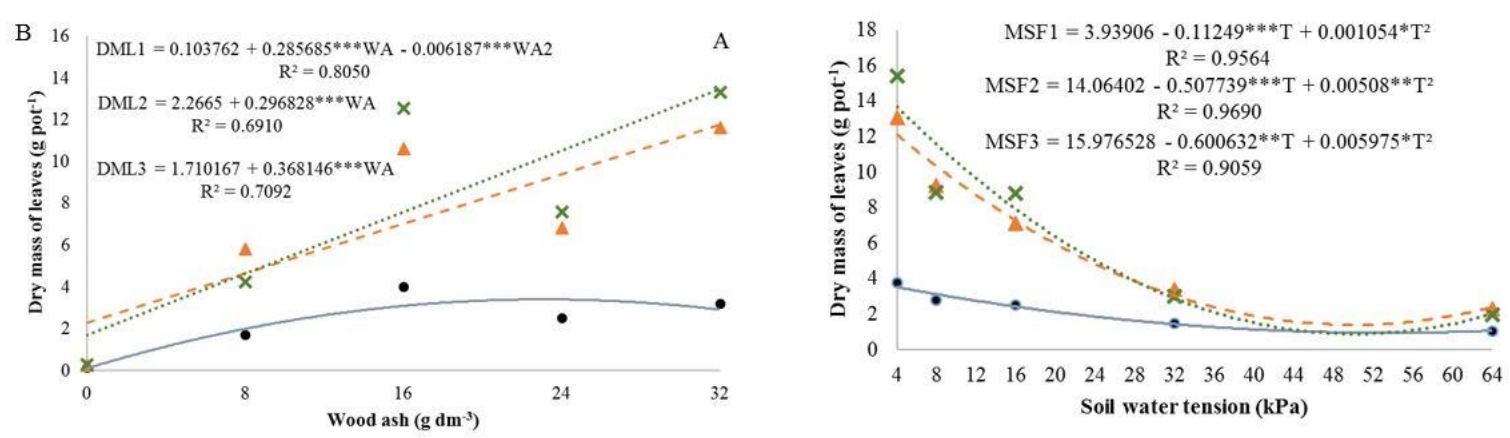

Figure 6. Dry mass of leaves of Urochloa brizantha cv. BRS Paiaguás in function of wood-ash doses (A) and soil water tensions (B) in the first, second and third cut.

; $\triangle$ and $X=$ first, second and third cut, respectively.

DML1, DML2 and DML3 = dry mass of leaves in the first, second and third cut, respectively. WA $=$ wood ash. $\mathrm{T}=$ soil water tension. ${ }^{*}, * *$ and $* * *$ significant at 5,1 and $0.1 \%$ probability.

In the second cut, the dry mass of leaves was adjusted to the linear and quadratic regression models for wood-ash doses and soil water tensions, respectively. The highest wood-ash dose, $32 \mathrm{~g} \mathrm{dm}^{-3}$, increased the dry mass of leaves by $80.74 \%$ (Figure $6 \mathrm{~A}$ ) compared to the absence of residue application. The soil water tension of $49.97 \mathrm{kPa}$ (Figure $6 \mathrm{~B}$ ) resulted in the smallest dry mass of leaves of $1.38 \mathrm{~g} \mathrm{pot}^{-1}$.

In the third evaluation of the forage grass, the dry mass of leaves was adjusted to the linear regression model, in which it presented an increase of $87.32 \%$ compared to the wood ash dose of $32 \mathrm{~g} \mathrm{dm}^{-3}$ with the treatment $0 \mathrm{~g} \mathrm{dm}^{-3}$ (Figure 6A). In relation to water tension in the soil, the dry mass of leaves was adjusted to the quadratic regression model, being the lowest value of $0.88 \mathrm{~g} \mathrm{pot}^{-1}$ observed in the soil water tension of $50.26 \mathrm{kPa}$ (Figure $6 \mathrm{~B}$ ).

In the three cuts, there was a lower dry mass of leaves of the grass when subjected to water tensions above $50 \mathrm{kPa}$ that confer low soil moisture. The research found that low soil moisture caused a lower production and could cause the death of the plants (Pezzopane et al., 2014). These authors verified a reduction of $50 \%$ in the dry mass of leaves of BRS Paiaguás subjected to water stress.

In a study of the production of Paiaguás grass under soil water tension, Koetz et al. (2017) found the largest dry mass of leaves, $44.12 \mathrm{~g} \mathrm{pot}^{-1}$, at the tension of $29 \mathrm{kPa}$, showing an increment of $50 \%$ when compared with the water tension of $60 \mathrm{kPa}$. On the other hand, in the present study, the production of dry mass of leaves decreased under soil water tensions higher than those found by Koetz et al. (2017).

Moreover, the effect of the wood-ash doses on the dry mass of the leaves of Paiaguás grass promoted an increment above $80 \%$. Thus, it can be inferred that the addition of existing nutrients in the wood ash suppressed the need for the plants to contribute to their better development, as observed by Hansen et al. (2017) and Maresca et al. (2017).

\subsection{Dry mass of stems}

The dry mass of the stems showed isolated effect for the treatments in the three cuts. In the first evaluation, the dry mass of the stems was adjusted to the quadratic regression model. The wood-ash dose of $28.63 \mathrm{~g} \mathrm{dm}^{-3}$ (Figure 7A) provided $1.96 \mathrm{~g} \mathrm{pot}^{-1}$ of the dry mass of the stems. The soil water tension of $50.23 \mathrm{kPa}$ (Figure 7B) caused the minimum production of $0.26 \mathrm{~g} \mathrm{pot}^{-}$ ${ }^{1}$ of dry mass of the stems. 

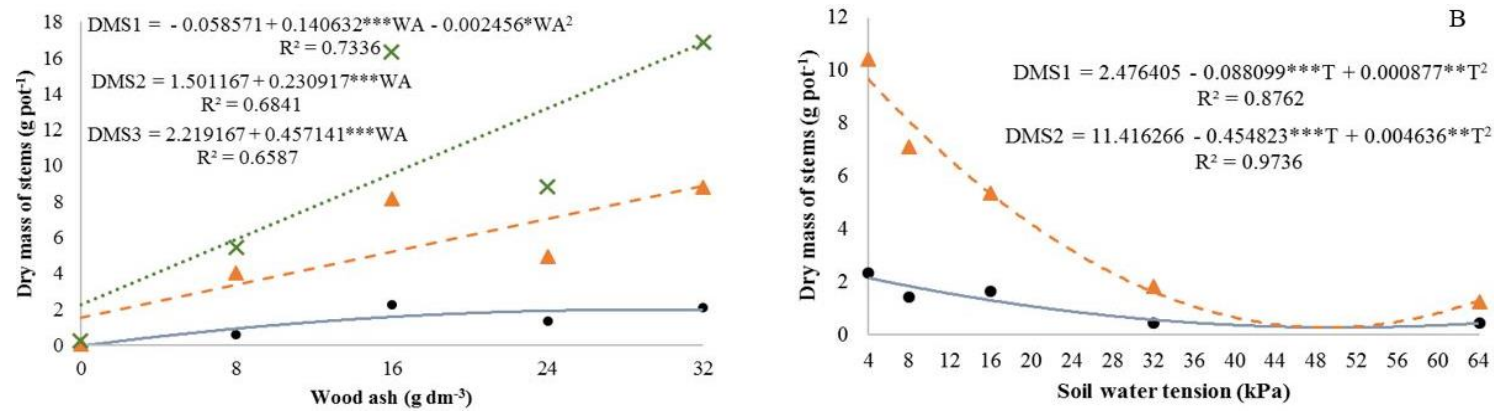

Figure 7. Dry mass of stems of Urochloa brizantha CV. BRS Paiaguás under wood-ash doses and soil water tension (B) on the first, second and third cut.

; and $\mathrm{X}=$ first, second and third cut, respectively.

DMS1, DMS2 and DMS3 = dry mass of stems in the first, second and third cut, respectively. $\mathrm{WA}=$ wood ash. $\mathrm{T}=$ tension of water in the soil. $*, * *$ and $* * *$ significant at 5,1 and $0.1 \%$, respectively.

In the second cut of the plants, the dry mass of the stems + sheaths was adjusted to the linear regression model, in which with the increase of the wood-ash doses increased $83.12 \%$ the production of Paiaguás grass (Figure 7A), when comparing the dose of $32 \mathrm{~g} \mathrm{dm}^{-3}$ with the noapplication of wood ash. For soil water tension, the dry mass of the stems was adjusted to the quadratic regression model, with lower yield of $0.26 \mathrm{~g} \mathrm{pot}^{-1}$, in the tension of $49.05 \mathrm{kPa}$ (Figure 7B).

In the last evaluation, the dry mass of the stems was adjusted to the linear regression model (Figure 7A), in which there was an increase of $86.83 \%$ in the production when the maximum wood ash dose was compared with the privation of the residue. There was no significant difference for dry mass of the stems under soil water tensions in this cut.

As was verified with the dry mass of leaves, the dry mass of the stems was lower when subjected to low water availability and presented higher dry matter production with the increment of wood ash. In cultivar analysis of $U$. brizantha, researchers found lower yield of dry mass of stems in plants cultivated under water deficit (50 kPa) (Kroth et al., 2015). Similarly, Pezzopane et al. (2014), obtained a reduction of the dry mass of stems of the Paiaguás grass in conditions of water stress.

With regard to fertilization by means of wood ash in grasses, studies show an increase in the production of dry mass of the stems in proportion to the increase in residue doses (Bezerra $e t$ al., 2016; Bonfim-Silva et al., 2013).

\subsection{Aerial part dry mass}

In the three cuttings of the grass, there was a significant difference between the wood-ash doses and soil water tensions. In the first cut, the aerial part dry mass was adjusted to the quadratic regression model for both factors. The wood ash dose of $24.66 \mathrm{~g} \mathrm{dm}^{-3}$ (Figure 8A) favored the highest production of aerial part dry mass of $5.3 \mathrm{~g} \mathrm{pot}^{-1}$. The lower dry mass production of the aerial part of $1.20 \mathrm{~g} \mathrm{pot}^{-1}$ was verified at the soil water tension of $51.97 \mathrm{kPa}$ (Figure 8B).

In the second evaluation, there was an increment (Figure 8A) in the aerial part dry mass of $81.76 \%$ when using the highest dose of the experimental interval compared to the treatment without application of wood ash. The adjustment of the aerial-part dry mass results was described by a quadratic regression model with minimum point $1.64 \mathrm{~g}$ pot- 1 in the soil water tension of $49.53 \mathrm{kPa}$ (Figure $8 \mathrm{~B}$ ).

In the third plant cut, the aerial-part dry mass of the grass was adjusted to the linear regression model with a progressive increase of $87.05 \%$ (Figure $8 \mathrm{~A}$ ) in the biomass production compared to the maximum dose with the treatment without fertilization with wood ash. The 
Paiaguás grass showed minimum dry-mass production of $0.20 \mathrm{~g} \mathrm{pot}^{-1}$, observed in the soil water tension $48.25 \mathrm{kPa}$ (Figure 8B).
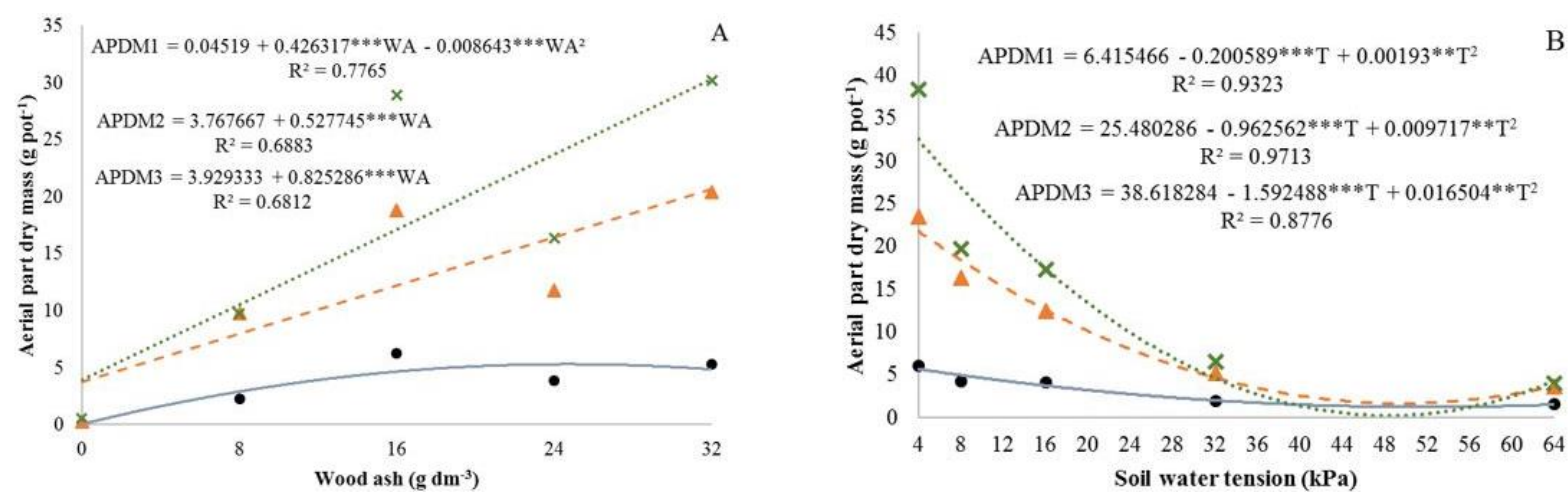

Figure 8. Aerial part dry mass of Urochloa brizantha CV. BRS Paiaguás subjected to wood-ash doses and soil water tension (B) on the first, second and third cut.

; $\triangle$ and $X=$ first, second and third cut, respectively.

APDM1, APDM2 and APDM3 = aerial part dry mass first, second and third cut, respectively. WA = wood ash. $\mathrm{T}=$ soil water tension. $* *$ and $* * *$ significant at 1 and $0.1 \%$ probability.

Evaluating the production of the cultivar BRS Piatã (Urochloa brizantha) cultivated in soils fertilizing with wood ash, researchers verified an increase in the aerial-part dry mass of the grass (Bonfim-Silva et al., 2017). The biomass gain was associated with the supply of the residue, which made phosphorus available within the optimum range recommended for Piatã grass.

In a study developed with the cultivars of $U$. brizantha, the aerial part dry mass was $47 \%$ lower in the treatments with water stress due to the reduction of stem and leaf dry mass (Pezzopane et al. 2014). This study corroborates this result, in which the second and third cut decreased the production of dry mass of the aerial part under soil water tensions above $48 \mathrm{kPa}$, as a consequence of the decrease of the dry mass of leaves and stems. Euclides et al. (2016) likewise verified a decrease in forage mass due to water stress during the dry season.

The aerial-part dry mass has a positive correlation with the structural characteristics of grasses, such as the number of leaves, tillers and leaf area (Megda and Monteiro, 2010), important aspects to define the most adequate management of pastures (Pereira et al., 2012).

\section{CONCLUSIONS}

The combinations of wood-ash doses with water soil tensions influence the productive characteristics of Paiaguás grass. Fertilization with wood ash reduces the effect of water stress on Paiaguás grass, and this residue may be a viable alternative to partial replacement of mineral fertilization and safe disposal in the environment.

\section{REFERENCES}

BALOCH, A. H.; REHMAN, H.; IBRAHIM, Z.; BUZDAR, M. A.; AHMAD, S. The biology of Balochistani weed: Cyperus rotundus Linnaeus. A Review. Pure and Applied Biology, n. 4, p. 171-180, 2015.

BEZERRA, M. D. L; BONFIM-SILVA, E. M.; SILVA, T. J. A. Wood ash effect on the productive characteristics of Marandu grass in Cerrado soils. African Journal of $\begin{array}{llllllll}\text { Agricultural } & \text { Research, } & \text { v } & 9, & \text { n. } & \text { 30, } & \text { p. 2339-2344, }\end{array}$ http://dx.doi.org/10.5897/2014.8841 
BEZERRA, M. D. L; BONFIM-SILVA, E. M.; SILVA, T. J. A.; SOUSA, H. H. F.; DUARTE, T. F.; ESPÍRITO SANTO, E. S.; PACHECO, A. B. Wood ash on the fertilization of Marandu grass in Brazilian cerrado soils. African Journal of Agricultural Research, v. 11, n. 17, p. 1504-1510, 2016. https://dx.doi.org/10.5897/AJAR2015.10729

BONFIM-SILVA, E. M.; CABRAL, C. E. A.; SILVA, T. J. A.; MOREIRA, J. C. F.; CARVALHO, J. C. S. Cinza vegetal: Características produtivas e teor de clorofila do capim-marandu. Bioscience Journal, v. 29, n. 5, p. 1214-1224, 2013.

BONFIM-SILVA, E. M.; MARTINEZ-SANTOS, T.; DOURADO, L. G.; FENNER, W.; SILVA, C. T. R.; SILVA, T. J. A. Wood Ash as a Corrective and Fertilizer in Safflower Crop in Oxisol of Brazilian Cerrado. Journal of Agricultural Science, v. 10, n. 9, p. 412-422, 2018. https://dx.doi.org/10.5897/AJAR2013.8278

BONFIM-SILVA, E. M.; PEREIRA, M. T. J.; SILVA, T. J. A.; SCARAMUZZA, W. L. M. P. Concentration of nitrogen, phosphorus and potassium in tropical grasses fertilised with wood ash in cerrado oxisol. African Journal of Agricultural Research, v. 9, n. 5, p. 549-555, 2014. http://dx.doi.org/10.4236/ajps.2015.69133

BONFIM-SILVA, E. M.; SANTOS, C. C.; SILVA, T. J. A. Wood ash fertilization on structural characteristics and chlorophyll index of tropical forage grasses. American Journal of Plant Sciences, v.6, p. 1341-1348, 2015. http://dx.doi.org/10.4236/ajps.2015.69133

BONFIM-SILVA, E. M.; PEREIRA, M. T. J.; SILVA, T. J. A.; FENNER, W. Potential of wood ash as a fertilizer in BRS Piatã grass cultivation in the brazilian Cerrado soil. $\begin{array}{llllll}\text { American Journal of Plant Sciences, v.8, p.2333-2344, } 2017 . & \end{array}$ https://doi.org/10.4236/ajps.2017.810156

CHANG, A. C.; LUND, L. J.; PAGE, A. L.; WARNEKE, J. E. Physical properties of fly ashamended soils. Journal of Environmental Quality, v.6, p.267-270, 1977. https://dx.doi.org/10.2134/jeq1977.00472425000600030007x

EMBRAPA. Centro Nacional de Pesquisa de Solos. Manual de métodos de análises de solo. 3. ed. Brasília, DF, 2017. 573p.

EUCLIDES, V. P. B.; MONTAGNER, D. B.; BARBOSA, R. A.; VALLE, C. B.; NANTES, N. N. Animal performance and sward characteristics of two cultivars of Brachiaria brizantha (BRS Paiaguás and BRS Piatã). Revista Brasileira de Zootecnia, v.45, n.3, p.85-92, 2016. http://dx.doi.org/10.1590/S1806-92902016000300001

EVERS, J. B.; KROL, A. R.; VOS, J.; STRUIK, P. C. Understanding shoot branching by modelling form and function. Trends in Plant Science, v. 16, n. 9, p. 464-467, 2011. https://doi.org/10.1016/j.tplants.2011.05.004

FERREIRA, D. F. Sisvar: a computer statistical analysis system. Ciência e Agrotecnologia, v.35, n.6, p. 1039-1042, 2011. http://dx.doi.org/10.1590/S1413-70542011000600001

GHODRATI, M.; SIMS, J. T.; VASILAS, B. L. Evaluation of fly ash as a soil amendment for the Atlantic Coastal Plain: I. Soil hydraulic properties and elemental leaching. Water, Air, and Soil Pollution, v.81, n.3, p.349-361, 1995. https://doi.org/10.1007/BF01104020

HANSEN, M.; BANG-ANDREASEN, T.; SØRENSEN, H.; INGERSLEV, M. Micro vertical changes in soil $\mathrm{pH}$ and base cations over time after application of wood ash on forest soil.

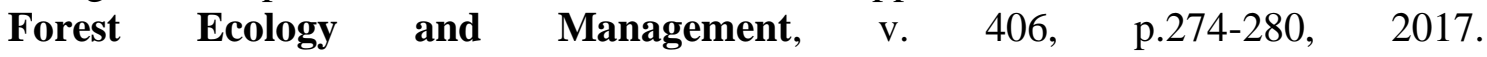
https://doi.org/10.1016/j.foreco.2017.09.069 
HANSEN, M.; KEPFER-ROJAS, S.; BJERAGER, P. E. R.; HOLM, P. E.; SKOV, S.; INGERSLEV, M. Effects of ash application on nutrient and heavy metal fluxes in the soil and soil solution in a Norway spruce plantation in Denmark. Forest Ecology and Management, v.424, p.494-504, 2018. https://doi.org/10.1016/j.foreco.2018.05.005

IBGE Resultados Preliminares do Censo Agro 2017. Available at: https://censos.ibge.gov.br/agro/2017/templates/censo_agro/resultadosagro/pecuaria.html Accesso: 27 Aug. 2018.

INGERSLEV, M.; SKOV, S.; SEVEL, L.; PEDERSEN, L. B. Element budgets of forest biomass combustion and ash fertilisation - a Danish case-study. Biomass Bioenergy, v.35, p.2697-2704, 2011. https://doi.org/10.1016/j.biombioe.2011.03.018

KOETZ, M.; BÄR, C. S. L. L; PACHECO, A. B.; CASTRO, W. J. R.; CRISOSTOMO, W. L.; BONFIM-SILVA, E. M. Produção e eficiência no uso da água do capim Paiaguás sob tensões de água no solo. Revista Brasileira de Agricultura Irrigada, v.11, n.1, p.12231232, 2017. https://dx.doi.org/10.7127/rbai.v11n100571

KROTH, B. E.; BONFIM-SILVA, E. M.; SILVA, T. J. A.; KOETZ, M.; SCHLICHTING, A. F. Cultivares de Brachiaria brizantha sob diferentes disponibilidades hídricas em Neossolo Flúvico. Revista Brasileira de Engenharia Agrícola e Ambiental, v.19, n.5, p.464-469, 2015. http://dx.doi.org/10.1590/1807-1929/agriambi.v19n5p464-469

LINDVALL, E.; GUSTAVSSON, A. M.; SAMUELSSON, R.; MAGNUSSON, T.; PALMBORG, C. Ash as a phosphorus fertilizer to reed canary grass: effects of nutrient and heavy metal composition on plant and soil. Gcb Bioenergy, v. 7, n. 3, p. 553-564, 2015. https://doi.org/10.1111/gcbb.12161

LITTELL, R. C.; MOTT, G. O. Computer assisted design and analysis of response surface experiments in agronomy. Soil and Crop Society of Florida Proceedings, v.34, p.9497, 1975.

MAEDA, S.; SILVA, H. D.; CARDOSO, C. Resposta de Pinus taeda à aplicação de cinza de biomassa vegetal em Cambissolo Húmico, em vaso. Pesquisa Florestal Brasileira, v. 28 , n. 56, p. 43-52, 2008.

MAHAJAN, S.; TUTEJA, N. Cold, salinity and drought stresses: An overview. Archives of $\begin{array}{lllll}\text { Biochemistry and } & \text { Biophysics, } & \text { v.444, 139-158, }\end{array}$ https://doi.org/10.1016/j.abb.2005.10.018

MARESCA, A.; HYKS, J.; ASTRUP, T. F. Recirculation of biomass ashes onto forest soils: ash composition, mineralogy and leaching properties. Waste Management, v.70, p.127138, 2017. https://doi.org/10.1016/j.wasman.2017.09.008

MARTINEZ-SANTOS, T. Compactação do solo e adubação com cinza vegetal na cultura do cártamo em solo do Cerrado Mato-grossense. 2018. 82f. Dissertação (Mestrado em Agricultura Tropical) - Faculdade de Agronomia e Zootecnia, Universidade Federal de Mato Grosso, Cuiabá, 2018.

MATTHEW, C.; ASSUERO, S. G.; BLACK, C. K.; SACKVILLE HAMILTON, N. R. Tiller dynamics of grazed swards. p.127-150. In: LEMAIRE, G.; HODGSON, J.; MORAES, A. (eds.). Grassland ecophysiology and grazing ecology. Wallingford: CABI Publishing, 2000. 
MAZAHRIH, N.; AL-WAHAIBI, H.; AL-FARSI, S.; OULED BELGACEM, A. Yield and water productivity of Buffel and Rhodes grasses under different irrigation water regimes using the sprinkler line-source system. Grassland Science, v. 62, n. 2, p. 112-118, 2016. https://doi.org/10.1111/grs.12120

MEGDA, M. M.; MONTEIRO, F. A. Nitrogen and potassium supply and the morphogenic and productive characteristics of Marandu palisadegrass. Revista Brasileira de Zootecnia, v. 39, n. 8, p. 1666-1675, 2010. http://dx.doi.org/10.1590/S1516-35982010000800007

OHNO, T. Neutralization of soil acidity and release of phosphorus and K by wood ash. Journal $\begin{array}{lllllll}\text { of Environmental Quality, } & \text { v. 21, p. 433-438, } 1992 .\end{array}$ https://dx.doi.org/10.2134/jeq1992.00472425002100030022x

PACHECO, A. B.; SILVA, T. J. A; BONFIM-SILVA, E. M.; CASTRO, H. A. W.; KOETZ, M. Yield and water use of cherry tomato under water availability and potassium doses. Revista Brasileira de Engenharia Agrícola e Ambiental, v.22, n.5, p.326-331, 2018. http://dx.doi.org/10.1590/1807-1929/agriambi.v22n5p326-331

PATHAN, S. M.; AYLMORE, L. A. G.; COLMER, T. D. Properties of several fly ash materials in relation to use as soil amendments. Journal of Environmental Quality, v.32, n.2, p.687-693, 2003. https://dx.doi.org/10.2134/jeq2003.6870

PEACOCK, J. M.; FERGUSON, M. E.; ALHADRAMI, G. A; McCANN, I. R.; AL HAJOJ, A.; SALEH, A.; KARNIK, R. Conservation through utilization: a case study of the indigenous forage grasses of the Arabian Peninsula. Journal of Arid Environments, v.54, n.1, p.15-28, 2003. https://doi.org/10.1006/jare.2001.0895

PEREIRA, L. E. T.; PAIVA, A. J.; da SILVA, S. C.; CAMINHA, F. O.; GUARDA, V. D.; PEREIRA, P. de M. Sward structure of Marandu palisadegrass subjected to continuous stocking and nitrogen-induced rhythms of growth. Scientia Agricola, v.67, n.5, p.531539, 2010. http://dx.doi.org/10.1590/S0103-90162010000500006

PEREIRA, M. T. J.; SILVA, T. J. A.; BONFIM-SILVA, E. M.; MAZZINI-GUEDES, R. B. Applying wood ash and soil moisture on gladiolus (Gladiolus grandiflorus) cultivation. Australian Journal of Crop Science, v.10, n.3, p.393-401, 2016.

PEREIRA, R. C.; RIBEIRO, K. G.; ANDRADE, R. D.; SILVA, J. L.; SILVA, E. B.; FONSECA, D. M.; CECON, P. R.; PEREIRA, O. G. Structural and productive characteristics of Marandu and Xaraés grasses fertilized at different times after harvesting. Revista Brasileira de Zootecnia, v.41, n.3, p.557-564, 2012. http://dx.doi.org/10.1590/S1516-35982012000300012

PEZZOPANE, C. G.; SANTOS P. M.; CRUZI, P. G. ALTOÉ, J.; RIBEIRO, F. A.; VALLE C. B. Estresse por deficiência hídrica em genótipos de Brachiaria brizantha. Ciência Rural, v.45, n.5, 2014.

RAMESH, C. V.; KORWAR, G. R.; MANDAL, U. K.; PRASAD, J. V. N. S.; SHARMA, K. L.; YEZZU, S. R.; KANDULA, V. Influence of fly ash mixtures on early tree growth and physicochemical properties of soil in semi-arid tropical Alfisols. Agroforestry Systems, v.73, n.1, p.13-22, 2008. https://doi.org/10.1007/s10457-008-9108-7

RANCANE, S.; KARKLINS, A.; LAZDINA, D.; BERZINS, P. Biomass yield and chemical composition of perennial grasses for energy production. Engineering for Rural Development, v. 14, p. 546-551, 2015. 
REED, E. Y.; CHADWICK, D. R.; HILL, P. W.; JONES, D. L. Critical comparison of the impact of biochar and wood ash on soil organic matter cycling and grassland productivity. Soil Biology and Biochemistry, v. 110, p. 134-142, 2017. https://doi.org/10.1016/j.soilbio.2017.03.012

REYNOLDS, M. P.; MUJEEB-KAZI, A.; SAWKINS, M. Prospects for utilising plant-adaptive mechanisms to improve wheat and other crops in drought- and salinity-prone environments. Annals of Applied Biology, v.146, p.239-259, 2005. https://doi.org/10.1111/j.1744-7348.2005.040058.x

ROBINS, J. G. Evaluation of warm-season grasses nutritive value as alternatives to cool-season grasses under limited irrigation. Grassland Science, v.62, p.144-150, 2016. https://doi.org/10.1111/grs.12123

SANTOS, C. C.; BONFIM-SILVA, E. M. SILVA, T. J. A. Tropical grass fertilized with wood ash in Cerrado Oxisol: Concentrations of calcium, magnesium and sulphur. African Journal of Agricultural Research, v.9, n.19, p. 1495-1501, 2014. https://dx.di.org/10.5897AJAR2014.8635

SAS INSTITUTE. SAS: user's guide: statistics. 9. ed. Cary, 2002. 943p.

SMITH, H. G.; SHERIDAN, G. J.; LANE, P. N. J.; NYMAN, P.; HAYDON, S. Wildfire effects on water quality in forest catchments: a review with implications for water supply. Journal of Hydrology, v. 396, n. 1-2, p. 170-192, 2011. https://doi.org/10.1016/j.jhydrol.2010.10.043

STOOF, C. R.; WESSELING, J. G.; RITSEMA, C. J. Effects of fire and ash on soil water $\begin{array}{llll}\text { retention. } & \text { Geoderma, } & \text { v.159, } 276-285, & \end{array}$ https://doi.org/10.1016/j.geoderma.2010.08.002

TAIZ, L.; ZEIGER, E. Fisiologia vegetal. 5. ed. Porto Alegre: Artmed, 2013. 954p.

VALLE, C. B.; EUCLIDES, V. P. B.; MONTAGNER, D. B.; VALÉRIO, J. R.; FERNANDES, C. D.; MACEDO, M. C. M.; VERZIGNASSI, J. R.; MACHADO, L. A. Z. BRS Paiaguás: A new Brachiaria (Urochloa) cultivar for tropical pastures in Brazil. Tropical Grasslands - Forrajes Tropicales, v.1, n.1, p.121-122, 2013.

WEINÄRTNER, M. A.; ALDRIGHI, C. F. S.; MEDEIROS, C. A. B. Práticas agroecológicas: adubação orgânica. Pelotas: EMBRAPA, 2006. 10p. 